\title{
MEASURING TRANSPARENCY IN THE DUTCH MORTGAGE MARKET ${ }^{* * * *}$
}

BY

\author{
WOLTER H.J. HASSINK* AND MICHIEL VAN LEUVENSTEIJN**,***
}

\begin{abstract}
Summary
This paper is an empirical study of pricing in the Dutch mortgage market. For a narrowly defined set of endowment mortgages (with a fixed lending rate of 10 years), we find that the price dispersion within lenders is larger than the dispersion across lenders. Prices remain dispersed across lenders, even after controlling for characteristics of the borrower, the municipality and the government bond rate. Apparently, the mortgage market is not fully transparent, which impedes competition in the mortgage market. We also find that the price dispersion for mortgages sold by banks is smaller than that for mortgages sold by other lenders. A likely explanation is that lenders using middlemen have higher agency costs.
\end{abstract}

Key words: agency costs, lender-borrower matched data, mortgage market, price dispersion, search costs

JEL Code(s): D40, D80, E43

\section{INTRODUCTION}

This paper is an empirical study of the transparency of the Dutch mortgage market and in particular of transparency in relation to the role of mortgage brokers or middlemen. Transparency is an important issue, as a lack of it impedes competition in the mortgage market. The paper is in line with earlier literature on competition in the Dutch loan market (e.g. Den Butter et al. (1977); Fase (1995); Swank (1995); Toolsema (2002)). The paper of Den Butter et al. (1977) is partly related to the present one, as it gives an econometric

\footnotetext{
* University of Utrecht, Utrecht School of Economics, Janskerkhof 12, 3512 BL Utrecht, The Netherlands, phone: +31 30253 9800, e-mail: w.hassink@econ.uu.nl

** CPB Netherlands Bureau for Economic Policy Analysis, The Hague, The Netherlands, phone: +31 70338 3488, e-mail: M.van.Leuvensteijn@cpb.nl

*** Department of Economics, Maastricht University, P.O. Box 616, 6200 MD Maastricht, The Netherlands

**** We wish to express our gratitude to the National Mortgage Guarantee (Nationale Hypotheek Garantie) in Zoetermeer, in particular Karel Schiffer and Hans Mersmann, for providing us access to their data as well as for their hospitality. We are grateful to Wim van Assenbergh, Harry Garretsen, Ralph de Haas, Jan Lemmen, Clemens Kool, Job Swank and two anonymous referees of this journal for their comments on previous versions of this article.
} 
model of the Dutch mortgage market with a demand and interest setting equation. Fase (1995) focuses on the uncertainty of measuring the loan rate and concludes that his empirical analysis supports the intuitive feeling that the rate of interest for bank credit is of great importance as instrument to control aggregate credit supply. Swank (1995) concludes that the mortgage market still has an oligopolistic structure in the Netherlands, although competition has intensified significantly in recent years. Toolsema (2002), on the other hand, finds indications for perfect competition among banks in the Dutch consumer credit market.

Our empirical analysis is based on a simple model. Because of imperfect information about lending rates, consumers have to incur search costs. Consequently, lending rates may become dispersed across lenders, even when the mortgages are homogeneous. In addition to consumer' search costs, lenders may incur agency costs as they have imperfect information on the creditworthiness of borrowers. Banks may have lower agency costs than other lenders (insurers and pension funds), especially when borrowers have been their clients for an extended period of time. Imperfect information renders mortgage markets less transparent; the size of dispersion in lending rates across lenders gives an indication of the lack of transparency of a market.

This paper can be considered as a follow-up study of Fase (1995), who states explicitly that lending rates may be dispersed across households. This paper introduces a new type of analysis of the Dutch mortgage market, by performing an empirical study of dispersion of the lending rate within and across mortgage suppliers. We are able to exploit a data set that contains administrative information on lending rates. We measure price dispersion for a homogeneous set of mortgages for residences (endowment mortgages with a fixed lending rate for 10 years) across lenders (banks, insurers and pension funds) for an extended period (January 1996 - September 2001). In addition, we focus on a market segment for which the borrowers are rather homogeneous with respect to risk and quality of the mortgage. Our data are from mortgages in the lower segment of the Dutch mortgage market and pertain to borrowers who acquired insurance against default risk from the Dutch National Mortgage Guarantee (NMG). The mortgages may not be used to refinance the home. As we focus on a homogeneous type of mortgage for a specific market segment, the advantage of our empirical analysis is that measurement problems do seem more remote than they usually are in related studies.

We find that lending rates are highly dispersed across lenders and that the within-lender dispersion across borrowers is somewhat smaller. From these findings, we conclude that the mortgage market is not transparent. Prices remain dispersed after controlling for the government bond rate and characteristics of the individual borrower and the region. We find that prices at the lender level are more dispersed for mortgages sold by insurers and pension funds than for mortgages sold by banks. This result may be due to imperfect 
information of borrowers (difference in transparency) and on the side of lenders (difference in agency costs between types of lender).

This article is organised as follows. Section 2 gives a theoretical background and describes the empirical model. Section 3 provides detailed information on the data set used. Section 4 examines the variation of the lending rates across borrowers and lenders over time. Section 5 gives the estimates. Section 6 concludes.

\section{THEORETICAL BACKGROUND AND EMPIRICAL MODEL}

Our starting point is the set up of Fase (1995), who models the demand for short-term bank credit at the macro level. The model of Fase (1995) contains three equations; the first is a demand equation, in which the stock of outstanding bank credit depends on (transformations of) the volume of expected sales, the yield on long-term government bonds and the (unobserved) lending rate of the bank loan. Second, his model contains a lending rate-setting equation, which has as explanatory variables the cost of capital and capital market conditions, because lenders operate in an oligopolistic setting. Basically, the lending rate for short-term bank loans depends on

$$
r^{*}=g(M)
$$

where $r^{*}$ is the unobserved lending rate at the macro level and $M$ is a vector of variables (transformations of the discount rate, the yield obtainable on alternative earning assets and the proportion of short-term deposits of the domestic sector in the banking system's total liabilities). Equation (1) is a macro equation, which relates aggregate phenomena in the capital market to price setting of banks (see also Swank (1995)). Fase (1995) includes in his model influences at the household level on the lending rate at the macro level. He thereto introduces a third equation that contains idiosyncratic effects on the lending rate that result from differences in lending opportunities among individual households.

Our empirical model for the mortgage market is based on the same principles, but the emphasis is reversed. In explaining the lending rate of mortgages, the major focus of our empirical model is on specific influences of individual lenders and borrowers in particular while allowing for macro influences. In this way, we are able to analyse empirically the dispersion of mortgage lending rates across lenders. We follow Fase (1995) by modelling a zone around the unobserved mortgage rate $\left(r_{j}^{*}\right)$

$$
r_{j}=r^{*}+u_{j},
$$

where $r$ is the observed mortgage lending rate. Subscript $j$ refers to the $j$ th household. The spread of the zone is captured by the variation of $u$, which is 
an identically and independently distributed (i.i.d.) error term with expected value of zero.

We extend equations (1) and (2) in the following way. First, equation (1) is modelled parsimoniously, by including a bond rate at the date of transaction of the mortgage $\left(r_{b}\right)$, for which the maturity is equal to that of the mortgage (i.e. both have the same fixed term). It serves as a benchmark, as it is an interest rate without the normal risks of a mortgage. It can also been interpreted as an approximation of the opportunity costs of lending a mortgage instead of investing in the market for government bonds. In this respect, we follow Den Butter et al. (1977) and Swank (1995), who include the bond rate in the lending rate equation. Second, we allow for the possibility that mortgage lenders may ask for different lending rates for individual borrowers as observable borrower characteristics reflect differences in risk. Hence, equations (1) and (2) become

$$
r_{j}=\gamma r_{b}+\beta^{\prime} X_{j}+v_{j}
$$

where $u_{j}=\beta^{\prime} X_{j}+v_{j} . X_{j}$ is a vector of observable characteristics of the household, the home and the regional home market. Sub-section 5.1 motivates these variables in further detail. $\gamma$ is a parameter; $\beta$ is a vector of parameters related to $X ; v$ is an i.i.d. error term with standard deviation $\sigma_{v}$. We extend equation (3), by allowing for differences in lending rate across lenders, which will be motivated below. The lending rate equation becomes

$$
r_{i j}=\alpha_{i}+\gamma r_{b}+\beta^{\prime} X_{i j}+v_{i j}
$$

where subscript $i$ refers to the $i$ th lender; $\alpha_{i}$ is a lender-specific effect. The standard deviation of $\alpha_{i}$ is referred to as $\sigma_{a}$. It is a measure of the betweenlender variation of the lending rate, conditional on $r_{b}$ and the vector $X$. We will explore the variation of $\alpha_{i}$ in greater detail below.

\subsection{Transparency of the Market}

The aim of the empirical analysis is to estimate dispersion of the lending rate across lenders, as it is informative about the transparency in the mortgage market. The variation of $\alpha_{i}$ across lenders will be limited when there are no consumers' search costs and the mortgages in equation (4) are homogeneous (for similar mortgages with a lending rate for the same fixed term). In that case, variation, if any, is likely to be small and limited to differences in operating costs across lenders.

There is a vast literature that explains the equilibrium price dispersion for homogeneous products by differences in consumers' search costs. When all consumers have equal search costs, then the equilibrium is the monopoly price (Diamond, 1971). However, when consumers are heterogeneous with 
respect to their search costs, there will be an equilibrium price distribution (e.g. Salop and Stiglitz (1977); Lach (2002)). It is expensive for borrowers to get an exhaustive overview of the lending rates for all lenders that operate on the mortgage market. Generally, consumers are no experienced buyers of mortgages; it is expensive to learn through frequent transactions from which lender to purchase at the lowest lending rate. We argue that there are no indications that borrowers have equal search costs, which implies that lending rates may be dispersed due to a lack of transparency of the mortgage market.

\subsection{Middlemen}

Next, we consider the role of middlemen and their influence on transparency in the mortgage market. Basically, there are two types of information channels in the Dutch mortgage market. As in other countries, banks, insurance companies and pension funds are suppliers at the Dutch mortgage market (Merriken, 1988). A striking difference between insurance companies and pension funds on the one hand and banks on the other is the distribution channel used to sell mortgages. Insurers and pension funds sell mortgages mainly through middlemen, whereas banks sell relatively more by direct faceto-face contacts at the desk. De Haas, et al. (2000) find that in 1999 large banks used middlemen as a distribution channel for only $20 \%$ of their transactions in mortgages. For small banks, this percentage was at most $70 \%$. According to NERA (1999), insurers distribute up to $79 \%$ of their products through intermediary channels, such as affiliated agents, brokers and even banks $(10 \%)$.

One could argue that middlemen increase the transparency in the mortgage market, so that dispersion of the lending rate across lenders is limited. Middlemen may provide borrowers with information about lending rates for a large part of the lending market (insurance companies, pension funds and banks), thus forcing mortgage lenders towards limited price dispersion across lenders. Hence, we would expect that dispersion in the mortgage market cannot be very large.

However, there are two major drawbacks to the use of middlemen. First, middlemen may be disinclined to provide exhaustive information on lending rates because of bonuses, provisions and discounts they may receive from certain lenders. As a consequence, price dispersion of lenders that make use of middlemen is likely to increase.

Second, banks may have more extensive and adequate information about borrowers than middlemen. It is more difficult to screen borrowers for creditworthiness through middlemen than by means of face-to-face contact at the desk. Middlemen provide limited information about the borrower, while lenders who meet clients at the desk are able to acquire more specific information. A bank may also have access to additional information about the borrower 
if that person has been the bank's client (e.g. by having an account or a credit card) for an extended period. The testable implication is that $\sigma_{a}$ will be smaller for banks that make use of additional information channels than for insurers and pension funds that make use of middlemen only ${ }^{1}$.

\subsection{Homogeneous Mortgages}

We will consider dispersion of the lending rate for a set of homogeneous mortgages. This refers both to the fixed-term of the lending rate and to the type of mortgage. An additional complication is that there may exist a lack of homogeneity, due to the lapse of time between the offer of the fixed lending rate and the formal signing of the mortgage contract at the notary. However, offers of fixed lending rates usually contain a clause to the effect that the lending rate at the date of signing the contract will be entered in the mortgage contract in case of an intervening decrease in the official lending rates. Usually, these changes are due to developments in the capital market, which can be measured by changes in the rates of government bonds. Hence, lending rates may be contaminated by measurement error in times of an increase in the official mortgages rates of lenders, as they may refer to the lending rate offered some months ago, for which the dates differ across borrowers. In contrast, the lending rates in periods of price decrease are free from measurement error, since they refer to the lending rate at the transaction date of the mortgage loan.

\section{DATA}

Our empirical analysis is based on a specific part of the Dutch mortgage market, as we make use of data provided by the NMG ('Nationale Hypotheek Garantie'). This guarantee was set up by the Dutch government in the mid-1990s in order to stimulate homeownership for the lower segment of the Dutch home market. In the Netherlands, homebuyers may opt to insure the risk of default with the NMG. They pay a small insurance premium $(0.15 \%$ of the mortgage loan) at the date of transaction of the mortgage and receive a discount on their lending rate in return (0.2-0.5 percentage points), since they pose no risk of default to the mortgage provider. Thus, the risk of default is covered by the NMG, but the repayment and prepayment risks remain for the lender. The criteria of eligibility for this guarantee are not stringent ${ }^{2}$. The value of the mortgage had to be below 420 thousand guil-

1 This is an indirect way of testing the role of middlemen. We have no additional information about middlemen to test the hypothesis directly.

2 These criteria are more stringent than the criteria for mortgages usually set by lenders. The maximum size of the mortgage loan depends on the gross income of both the head of the household 
ders in 2000 and 2001 and the loan-to-value ratio could not exceed $88 \%^{3,4}$. Thus, our analysis concentrates on the lower segment of the Dutch mortgage market.

The NMG provides a guarantee against the risk of default. In case of default of the homeowner, the NMG is liable for the remaining debt. The NMG will make arrangements with the homeowner to pay back this sum to the NMG over an extended period of time. Between 1995 and 2001, about 393,000 households obtained an NMG guarantee, 194 of which (about 0.05\%) defaulted in those years. In the same period, the guarantee of the NMG gained a nearly countrywide coverage ${ }^{5}$. The potential market share is based on the value of the home, taking into account the additional costs that have to be made to acquire the home and that must be financed by mortgages. The NMG estimated that in $199725 \%$ of the total mortgage market actually acquired an NMG guarantee. In 2001, this percentage had increased to $26 \%$ (NHG, 2002).

We have access to data from the NMG over the period January $1995-$ October 2001. Our data set contains all transactions of homeowners who received the guarantee by the NMG in this period. The NMG data have an administrative purpose as they were used to assess the eligibility of individual households. Each case contains information on the borrower's characteristics, which includes gross annual income (distinguished by head of household and partner), address of the home, all necessary aspects of the mortgage contract (name of mortgage lender, lending rate, type of mortgage, size of the loan and date of transaction), and some household characteristics (date of birth of head of household and partner, type of home and number of homeowners). The date of transaction of the mortgage loan is the first day on which the borrower starts paying interest payments to the lender.

We linked our data on households with two other data sets, i.e. a data set pertaining to the municipality and data with daily information on the 10-year government bond rate $^{6}$. The municipality data are collected by Statistics Netherlands and were available for 1999 only $^{7}$. We used municipality-level information on the population density, the number of inhabitants in the municipality and the average value of homes in a municipality as used by

\footnotetext{
Footnote 2 Continued and the partner. Furthermore, the maximum size depends on the value of the home (NMG, 2002).

3 In 2002, the NMG required that a maximum of $28-37 \%$ of gross income (depending on household income and interest rate) may be attributed to spending on housing.

41 Dutch Guilder (Gld.) is worth 0.45 euros.

5 A few large communities joined the NMG during our period of investigation: Groningen in January 1999, Rotterdam in January 2000 and Arnhem mid-2001. The NMG reached full countrywide coverage in 2001.

6 Statistics Districts and Neighbourhoods 1999.

7 Except for the average WOZ value, which is available for 1st January 1995.
} 
the tax authorities (in Dutch: 'WOZ-waarde'). The value used by the tax authorities is on average considerable lower than the market value. The data on daily information on the 10-year government bond rate are collected by Dutch Central Bank, which is matched using the transaction date of the mortgage loan ${ }^{8}$.

In addition, we determined whether the lender was a bank, insurance company or pension fund. Our categorization of banks is based on the definition of Bankscope (for banks) and the definition of the Pensions and Insurance Supervisory Authority of the Netherlands, the supervising body of insurance companies.

Our gross sample of household data consists of 386,335 mortgages of dwellings covering all maturities. Figure 1 gives the distribution of the mortgages' fixed interest rate period. The largest class of mortgages is that of a 10 -year period with fixed lending rates $(154,874$ cases or $40 \%$ of the gross sample). We selected these 10-year mortgages. Second, we excluded the cases for which the income of the head of the household was not reported as well as the cases for which the mortgages were used to refinance the home. Third, cases observed in 1995 were excluded, because not all explanatory variables were available for that year. Finally, cases from October 2001 were excluded because information on the dates at the end of that month was lacking, which could affect the analyses with the monthly lending rates in section 4 . Eventually, our sample was reduced to 130,842 cases, that were observed in the period January 1996 - September 2001 (69 calender months $)^{9}$. For these cases, $65 \%$ of the mortgages are based on endowment; $32 \%$ are other mortgages including escrow mortgages; $3 \%$ of the mortgages are annuity mortgages. In order to have a homogenous type of mortgage (so that there are no measurement errors due to differences in the type of contract), we restricted our sample to the endowment mortgages. It leads to a sample of 84,727 cases, which will be used in section 4 and sub-sections 5.1 and 5.2.

This sample may be distinguished by type of lender, i.e. banks, insurance companies, and other lenders. Table 1 gives the mortgage distribution by type of lender in our sample. Banks provide about $70 \%$ of the mortgages, insurers $12 \%$, and the other lenders 18\%. There are 72 mortgage lenders: 21 banks, 25 insurers and 26 other suppliers (including pension funds).

As indicated above, our sample focuses on the lower part of the Dutch mortgage market. The distribution of mortgages by type of provider in our sample may therefore differ from that of Statistics Netherlands for the full mortgage market (see Table 2). According to Statistics Netherlands, over the period 1993-2001, the market share of banks increased from $48.6 \%$ (1993) to

8 Statistics T3.8.1 Market interest rates, Table 3.1.3.

9 In addition, we omitted a few cases that had an outlier in the lending rate (13 cases with a lending rate above $15.0 \%$ or below $3.0 \%$ ), the income of the head of household (four cases) and the partner (two cases), the number of homeowners (six cases), and the premium deposit (two cases). 


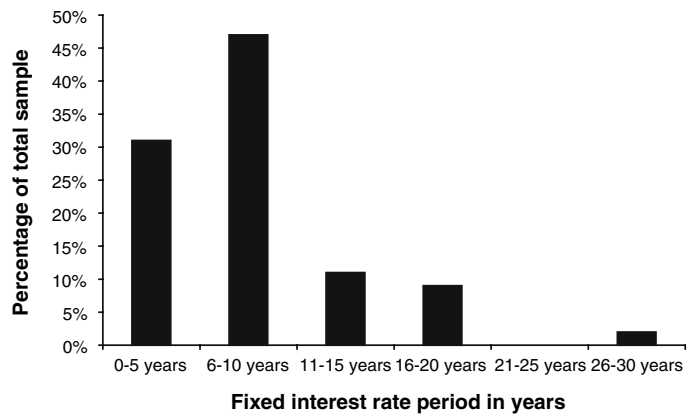

Figure 1 - Distribution of the fixed interest rate period (in years), January 1996-October 2001; $N=386,335$

TABLE 1 - MORTGAGES BY TYPE OF LENDER

\begin{tabular}{llll}
\hline Lender & Number of lenders & Number of borrowers & Percentage of mortgages \\
\hline Banks & 21 & 59,434 & $70 \%$ \\
Insurance companies & 25 & 10,070 & $12 \%$ \\
Other lenders & 26 & 15,223 & $18 \%$ \\
Total & 72 & 84,727 & $100 \%$ \\
\hline
\end{tabular}

nearly 50\% (1997 and 1998), and to decline again to $43.8 \%$ in 2001 . For the insurance companies, the market share was $15.8 \%$ in 1993 ; it fluctuated in the subsequent years and dropped to $12.6 \%$ in 2001 . The remaining suppliers have a market share that increased from $35.6 \%$ in 1993 to $43.6 \%$ in 2001.

TABLE 2 - MARKET SHARES IN THE DUTCH MORTGAGE MARKET BY LENDER' TYPE

\begin{tabular}{llll}
\hline & Banks $(\%)$ & Insurance companies $(\%)$ & Other lenders $(\%)$ \\
\hline 1993 & 48.6 & 15.8 & 35.6 \\
1994 & 47.8 & 15.6 & 36.6 \\
1995 & 43.5 & 12.0 & 44.6 \\
1996 & 46.6 & 12.6 & 40.9 \\
1997 & 49.9 & 15.6 & 34.5 \\
1998 & 49.9 & 13.4 & 36.6 \\
1999 & 45.8 & 14.4 & 39.8 \\
2000 & 46.3 & 13.6 & 40.1 \\
2001 & 43.8 & 12.6 & 43.6 \\
\hline
\end{tabular}

Source: Statistics Netherlands. 
We will analyse dispersion of the lending rate by type of lender separately. Our analysis in sub-section 5.3 is based on information of 59,434 mortgages sold by banks and 25,293 mortgages sold by insurers and pension funds. In addition, we will distinguish periods in which the bond rate decreased from periods that had an increase in the bond rate. We constructed a variable which has the value of one when the bonds' interest rate goes up compared with the preceding 2 months and the value of zero when this interest rate decreased compared with the preceding 2 months. The bond market interest rate is used as an exogenous variable that indicates whether the market was going up or down, which is in line with Toolsema and Jacobs (2001). Den Butter et al. (1977) and Swank (1995) demonstrate the importance of the capital market interest rate for the mortgage rate charged.

\section{DISPERSION OF THE LENDING RATE}

This section examines the dispersion of the lending rate and its development over time. We consider variation within the month of transaction of the mortgage. Even though we use a narrowly defined set of mortgages, we find that the lending rate varies substantially across lenders and borrowers.

\subsection{Between-Lender Dispersion}

First, we consider the variation in lending rate across lenders. We calculated the average lending rate, $\overline{r_{i}}$, for each of the lenders (subscript $i$ ) during that month (subscript $t$ ). For each month, we determined for $\bar{r}_{i t}$ a $95 \%$ interval estimate across all of the lenders. The average width of the interval over all months is 0.96 percentage point ${ }^{10}$. It is a first indication that the dispersion of the average lending rate across lenders is quite substantial.

Next, we are interested in the skewness of the distribution of the average lending rate across the lenders, for which we compare the average and the median of the distribution. For each month $t$, we calculated the average of $\overline{r_{i t}}$ (across lenders) and the median of $\overline{r_{i t}}$ (across lenders) that we refer to as $\overline{r_{t}}$ and $\xi_{t}^{50}$, respectively. The average of $\overline{r_{t}}-\xi_{t}^{50}$ over all months equals -0.011 percentage point, which indicates that the distribution (across lenders) of the average monthly lending rate is skewed to the right; it has a tail on the left hand side of the distribution ${ }^{11}$.

Next, we examine the development of the between-lender dispersion of the lending rate over time. In this respect, we use the median lending rate $\left(\xi_{i t}^{50}\right)$ for each lender and each month. We do not apply the average lending

10 This measure allows us to compare it with the standard deviation of the between-lender dummies in section 5 .

11 The skewness does not change substantially when we consider different regimes of upward and downward change of the bond rate. 


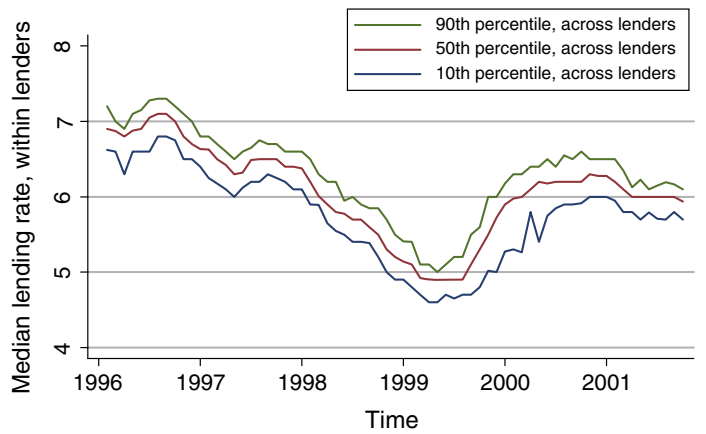

Figure 2 - Dispersion of monthly median lending rate; $10^{\text {th }}, 50^{\text {th }}$ and $90^{\text {th }}$ percentile (across lenders)

rate, $\bar{r}_{i t}$, as the median is less sensitive to outliers. For each month and each lender, we calculated the median lending rate $\xi_{i t}^{50}$ across its borrowers. For each month, we determined the $10^{\text {th }}, 50^{\text {th }}$ and $90^{\text {th }}$ percentile of the median lending rate $\xi_{i t}^{50}$ across the distribution of lenders. Figure 2 shows the development of these three percentiles over time. The difference of the $90^{\text {th }}$ and the $10^{\text {th }}$ percentile of the median lending rate is a measure of the between-lender dispersion ${ }^{12}$. The average of this difference over all months is 0.56 percentage point.

The figure shows that the median lending rate decreased from about $7 \%$ to about 5\% over the period January 1996-July 1999. July 1999 is a turning point; from then on the median lending rate increased by about one percentage point to $6 \%$ in a few months. From January 2000 onwards, the median lending rate remained stable at the $6 \%$ level. With respect to the difference of the $90^{\text {th }}$ and the $10^{\text {th }}$ percentile, we notice two regimes. In the first regime of decreasing lending rates (until July 1999), the average difference was 0.52 percentage point. The difference increased to 0.64 percentage point in the second regime of an increasing rate at the market level. The widening of the dispersion may point at higher price competition of the lenders to increase their market share in times of increasing lending rates.

\subsection{Within Lender-Dispersion}

Next, we consider the dispersion of the lending rate at the borrower level. For each month and each lender, we calculated the difference of the average lending rate and the median lending rate $\left(r_{i t}-\xi_{i t}^{50}\right)$. The average of this difference across all lenders and months is relatively small but negative $(-0.0046$

12 We did not take the minimum and maximum of the median lending rate, so that the outcomes are less sensitive to outliers. 


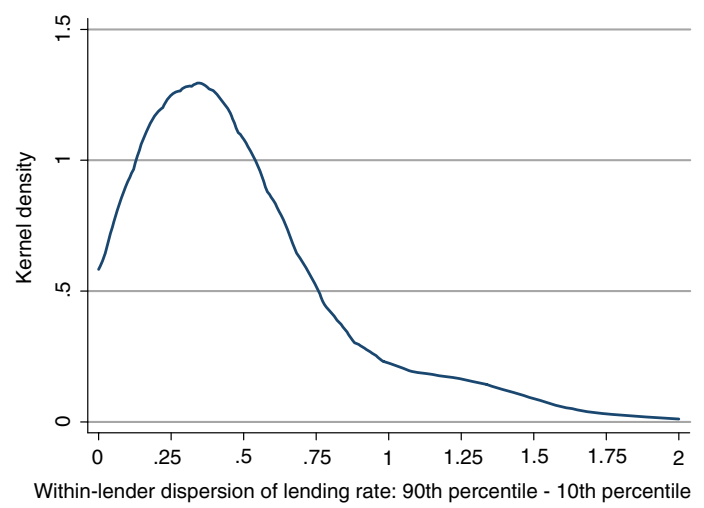

Figure 3 - Kernel estimate of monthly within-lender dispersion of lending rate; at least two borrowers per month ${ }^{\text {a) }}$ a) Explanatory note: We applied an Epanechnikov density Kernel (see Footnote 13)

percentage point for 3,087 observations; it remains about the same when we distinguish between regimes of upward and downward changes of the bond rate). It implies that the distribution of the lending rate within lenders is not fully symmetric; the distribution has a tail on the left-hand side.

We consider the difference between the $90^{\text {th }}$ and the $10^{\text {th }}$ percentile of the lending rate across the borrowers, $\left(\xi_{i t}^{90}-\xi_{i t}^{10}\right)$ for each lender and each period. It gives us a measure of the within-lender dispersion. Figure 3 gives an estimate of the distribution of the within-lender dispersion across the lenders. We applied a Kernel estimator ${ }^{13}$, for which we used those monthly observations for which the lender had at least two borrowers during the month $(2,547$ observations). It appears that the modus of the within-lender dispersion $\xi_{i t}^{90}-\xi_{i t}^{10}$ is about 0.3 percentage point. A comparison of the between-lender dispersion (Figure 2) and the within-lender dispersion (Figure 3) indicates that the dispersion is smaller within lenders (among borrowers) than between lenders.

Figure 4 shows the development of the within-lender dispersion over time. We are interested in two percentiles across the distribution of lenders: the lenders that have a relatively small or large within-dispersion of the lending rate. For each month, we determined the $10^{\text {th }}$ percentile and the $90^{\text {th }}$ percentile of the within-lender dispersion, using the same monthly observations as in Figure 3. Remarkably, the within-lender dispersion fluctuates substantially over time. In particular, around 2000, when there was a rapid increase in the

13 The Kernel density estimator is a nonparametric density estimator (e.g. Cameron and Trividi, 2005, pp. 298-306). We applied an Epanechnikov Kernel, with a range of 0-2.0 percentage point and a bandwith of 0.125 percentage point. 


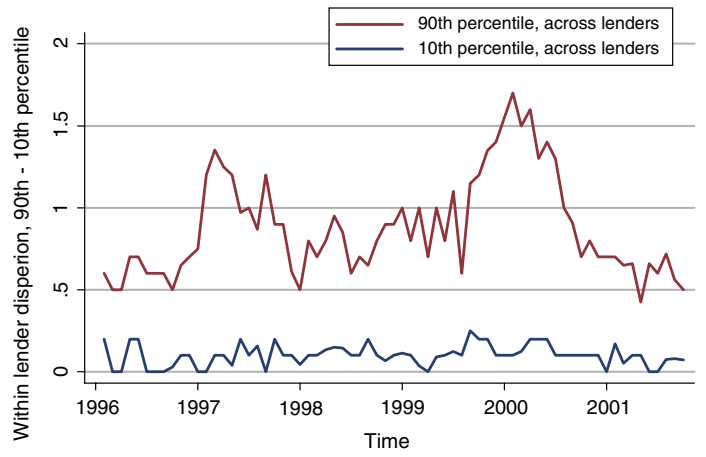

Figure 4 - Development over time of monthly within-lender dispersion of lending rate; at least two borrowers per month

lending rate (see Figure 2), the dispersion of $\xi_{i t}^{90}-\xi_{i t}^{10}$ becomes substantially larger.

\section{ESTIMATES}

\subsection{Explanatory Variables}

The purpose of this section is to estimate the between-lender dispersion of the lending rate, conditional on the observed characteristics of the borrowers, their property and the opportunity costs of investment. Basically, it boils down to estimating the size of the between-lender variation from equation (4). This sub-section motivates the inclusion of the explanatory variables in the vector $X$ in equation (4). The choice of our explanatory variables is based on the micro-econometric studies of Duca and Rosenthal (1994), Chiang and Chow (2002) and Nothaft and Perry (2002). The descriptive statistics of the explanatory variables are given in Table 3 . As motivated in section 3 , we make use of the data of endowment mortgages (84,727 observations). For these data, the average lending rate is $6.02 \%$. Seventy percent of the borrowers purchased their mortgage from a bank.

We first discuss the characteristics of the borrowers. Inclusion of the value of the home, the gross income variables and the value of the mortgage jointly (all of these variables in logarithms) would lead to severe problems of multicollinearity, as these variables are strongly correlated. Instead, we included both the (logarithm of the) value of the mortgage loan relative to that of the home, the so-called loan-to-value ratio, and the (logarithm of the) mortgage loan relative to the gross household income (refered to as the loan-to-income ratio). Moreover, we included the (logarithm of the) gross household income 
TABLE 3 - DESCRIPTIVES; ENDOWMENT MORTGAGES; FIXED LENDING RATE OF 10 YEARS

\begin{tabular}{|c|c|c|c|c|}
\hline Variable & Mean & Std. Dev. & Min. & Max. \\
\hline \multicolumn{5}{|l|}{ Characteristics of mortgage } \\
\hline Lending rate (in percentages) & 6.02 & 0.65 & 3.25 & 10.00 \\
\hline Dummy bank & 0.70 & 0.46 & 0 & \\
\hline \multicolumn{5}{|l|}{ Characteristics of borrower } \\
\hline $\log$ (value of mortgage) & 12.34 & 0.335 & 9.68 & 12.95 \\
\hline $\log$ (gross income of head household) & 10.82 & 0.32 & 7.48 & 13.73 \\
\hline $\log ($ gross income of partner +1$)$ & 6.31 & 5.16 & 0 & 13.45 \\
\hline Loan/(value of home) & 1.02 & 0.13 & 0.09 & 1.92 \\
\hline Loan/(gross income head + gross income partner) & 3.23 & 0.65 & 0.01 & 8.51 \\
\hline Dummy age $\leq 25$ years & 0.19 & 0.39 & 0 & \\
\hline Dummy $25<$ age $\leq 30$ years & 0.40 & 0.49 & 0 & \\
\hline Dummy $30<$ age $\leq 35$ years & 0.22 & 0.41 & 0 & \\
\hline Dummy $35<$ age $\leq 40$ years & 0.10 & 0.30 & 0 & \\
\hline Dummy $40<$ age $\leq 45$ years & 0.05 & 0.22 & 0 & \\
\hline Dummy $45<$ age $\leq 50$ years & 0.03 & 0.16 & 0 & \\
\hline Dummy age $>50$ years & 0.01 & 0.10 & 0 & \\
\hline Dummy one borrower & 0.29 & 0.45 & 0 & \\
\hline Log(instalment payments +1$)$ & 4.96 & 5.52 & 0 & 12.24 \\
\hline $\log ($ premium deposit +1$)$ & 0.81 & 2.52 & 0 & 12.04 \\
\hline \multicolumn{5}{|l|}{ Characteristics of home } \\
\hline Dummy existing home & 0.84 & 0.37 & 0 & \\
\hline Dummy apartment & 0.20 & 0.40 & 0 & \\
\hline Dummy back repair of the home & 0.04 & 0.19 & 0 & \\
\hline \multicolumn{5}{|l|}{ Characteristics of municipality } \\
\hline Population density per square kilometre (in thousands) & 0.17 & 0.17 & 0.03 & 0.65 \\
\hline Number of inhabitants (in ten thousands) & 1.08 & 1.43 & 0.01 & 7.27 \\
\hline $\log$ (average value of homes) (in thousands of guilders) & 5.10 & 0.22 & 4.47 & 6.12 \\
\hline \multicolumn{5}{|l|}{ Benchmark interest rate } \\
\hline $\begin{array}{l}\text { Interest on 10-year government bonds (at } \\
\text { date of purchase of mortgage) }\end{array}$ & 5.24 & 0.61 & 3.73 & 6.58 \\
\hline Number of observations & \multicolumn{4}{|c|}{84,727} \\
\hline
\end{tabular}

both for the head of the household and for the partner ${ }^{14}$. Both the loanto-value ratio and the loan-to-income ratio are informative about the risk of prepayment (since there is no risk of default as this is covered by the NMGinsurance). Lenders require a higher lending rate when households have a higher risk of prepayment. A lower loan-to-value ratio leads to an increase in the risk of prepayment, so that there will be a higher lending rate, as the borrower becomes more attractive for competing lenders. A higher loan-toincome ratio leads to a higher risk of prepayment, because borrowers have

14 Inclusion of the $\log$ (loan-to-value), the $\log$ (loan-to-income) and $\log$ (income) makes it possible to identify the effects of $\log$ (income), $\log (\operatorname{loan})$ and $\log ($ value) separately. 
more to gain from prepayment when the loan is relatively high compared with their income. The average loan-to-value ratio is 1.022; the loan-to-income ratio is on average 3.232 (see Table 3).

Although the NMG-insurance imposes no constraint on the household income, the households are from the lower segment of the income distribution, as this insurance is aimed at the lower part of the home market (see section 3). The average value of the mortgage is 237 thousand guilders (in logs: 12.34). The average gross income of the head of the household is about 52 thousand guilders (average of log: 10.82) ${ }^{15}$. For the partner of the head of the household, the average gross income is about 24 thousand guilders (average of log: $6.31)^{16,17}$.

On average, the homebuyers are young; 59\% of the borrowers are at most 30 -years-old. This may be due to the segment of the housing market the NMG-insurance focuses its activities on, since young people buy relatively more homes in this segment. $29 \%$ of the mortgages have one borrower only. The average value of the instalment payments is about 37 thousand guilders (average of log: 4.96). The average value of the premium deposit is 930 guilders (average of log: 0.81) ${ }^{18}$.

The characteristics of the home provide information on whether the property is new, whether it is an apartment, and whether the home needs back repair. $84 \%$ of the mortgages are used for existing homes, $20 \%$ are used for apartments and $4 \%$ of the mortgaged homes need back repair.

We used various characteristics of the municipality, which refer to the situation on 1 January 1999. On average, there are about 170 inhabitants per square kilometre (so the major part of the households live in non-urbanized areas). On average, a municipality has around 10,800 inhabitants. The average value of the homes in the municipality, on which local taxes are based, is 168 thousand guilders (average of log: 5.1) on 1 January 1995. On average, the interest rate on 10 -year bonds is $5.1 \%$, which is about 0.9 percentage point lower than the average lending rate.

Table 4 gives the means and standard deviations of these variables for the mortages sold by banks (59,434 cases) and by insurers and pension funds (25,293 cases) separately. The differences between both types of lender seem

15 In the Netherlands, homeowners receive tax reduction on their interest rate costs of the mortgage. The degree of tax reduction depends on the marginal tax rate. The marginal tax rates were $33 \%, 42 \%$, and $62 \%$ in the period $1996-2000$. In 2001 , the marginal tax rates were $37 \%, 42 \%$, and $52 \%$.

16 About one third of the borrowers has no partner with an income; therefore, the difference between the log of the average gross income of the partner and the average of the log is quite substantial.

17 In this section the averages of the prices are calculated for the untransformed variables. Table 3 gives the averages of the transformed variables.

18 About $50 \%$ of the borrowers have an installment premium; about $30 \%$ of the borrowers have a premium deposit. 
TABLE 4 - DESCRIPTIVES DISTINGUISHED BY TYPE OF LENDER

\begin{tabular}{|c|c|c|c|c|}
\hline \multirow[t]{2}{*}{ Variable } & \multicolumn{2}{|c|}{ Banks } & \multicolumn{2}{|c|}{$\begin{array}{l}\text { Insurance companies } \\
\text { and pension funds }\end{array}$} \\
\hline & Mean & Std. Dev. & Mean & Std. Dev. \\
\hline \multicolumn{5}{|l|}{ Characteristics of mortgage } \\
\hline Lending rate (in percentages) & 5.93 & 0.65 & 6.23 & 0.60 \\
\hline \multicolumn{5}{|l|}{ Characteristics of borrower } \\
\hline $\log$ (value of mortgage) & 12.33 & 0.31 & 12.29 & 0.30 \\
\hline Log(gross income of head household) & 10.82 & 0.33 & 10.79 & 0.31 \\
\hline $\log ($ gross income of partner +1$)$ & 6.27 & 5.17 & 6.41 & 5.13 \\
\hline Loan/(value of home) & 1.02 & 0.13 & 1.02 & 0.13 \\
\hline $\begin{array}{l}\text { Loan/(gross income head }+ \text { gross income } \\
\text { partner) }\end{array}$ & 3.27 & 0.66 & 3.14 & 0.62 \\
\hline Dummy age $\leq 25$ years & 0.19 & 0.39 & 0.18 & 0.39 \\
\hline Dummy $25<$ age $\leq 30$ years & 0.39 & 0.49 & 0.41 & 0.49 \\
\hline Dummy $30<$ age $\leq 35$ years & 0.21 & 0.41 & 0.23 & 0.42 \\
\hline Dummy $35<$ age $\leq 40$ years & 0.10 & 0.31 & 0.10 & 0.30 \\
\hline Dummy $40<$ age $\leq 45$ years & 0.05 & 0.23 & 0.05 & 0.21 \\
\hline Dummy $45<$ age $\leq 50$ years & 0.03 & 0.17 & 0.02 & 0.14 \\
\hline Dummy age $>50$ years & 0.01 & 0.11 & 0.01 & 0.09 \\
\hline Dummy one borrower & 0.30 & 0.46 & 0.26 & 0.44 \\
\hline $\log ($ instalment payments +1$)$ & 5.31 & 5.63 & 4.13 & 5.39 \\
\hline $\log ($ premium deposit +1$)$ & 0.98 & 2.72 & 0.41 & 1.90 \\
\hline \multicolumn{5}{|l|}{ Characteristics of home } \\
\hline Dummy existing home & 0.83 & 0.38 & 0.86 & 0.35 \\
\hline Dummy apartment & 0.20 & 0.40 & 0.19 & 0.40 \\
\hline Dummy back repair of the home & 0.05 & 0.21 & 0.03 & 0.16 \\
\hline \multicolumn{5}{|l|}{ Characteristics of municipality } \\
\hline $\begin{array}{l}\text { Population density per square kilometre (in } \\
\text { thousands) }\end{array}$ & 0.17 & 0.17 & 0.18 & 0.17 \\
\hline Number of inhabitants (in ten thousands) & 1.07 & 1.43 & 1.10 & 1.42 \\
\hline $\begin{array}{l}\text { Log(average value of homes) (in thousands } \\
\text { of guilders) }\end{array}$ & 5.09 & 0.22 & 5.11 & 0.21 \\
\hline \multicolumn{5}{|l|}{ Benchmark interest rate } \\
\hline $\begin{array}{l}\text { Interest on 10-year government bonds (at } \\
\text { date of purchase of mortgage) }\end{array}$ & 5.15 & 0.59 & 5.44 & 0.60 \\
\hline Number of observations & \multicolumn{2}{|c|}{59,434} & \multicolumn{2}{|c|}{25,293} \\
\hline
\end{tabular}

to be rather small for most of the variables. The nominal lending rate is somewhat lower for the banks than for the insurers and pension funds, but this could be due to different days of observation. Banks and insurance companies and pension funds have an equal difference between the lending rate and the interest on 10-year government bonds. 
TABLE 5 - ESTIMATES OF EQUATION (4); DEPENDENT VARIABLE: LENDING RATE; ROBUST STANDARD ERRORS

\begin{tabular}{lrc}
\hline Explanatory variable & Parameter & $t$-value \\
\hline Characteristics of borrower & & \\
Log(income of head household) & -0.033 & $-8.50^{* *}$ \\
Log(income of partner + 1) & -0.003 & $-8.43^{* *}$ \\
Log[Loan/(value of home)] & -0.117 & $-19.52^{* *}$ \\
Log[Loan/(gross income head + gross income partner)] & 0.009 & 1.14 \\
Dummy age $\leq 25$ years a) & 0.002 & 0.16 \\
Dummy 25 < age $\leq 30$ years & -0.010 & -0.86 \\
Dummy 30 < age $\leq 35$ years & -0.007 & -0.63 \\
Dummy 35 < age $\leq 40$ years & -0.005 & -0.47 \\
Dummy 40 < age $\leq 45$ years & 0.001 & 0.05 \\
Dummy 45 < age $\leq 50$ years & -0.010 & -0.75 \\
Dummy more than one borrower b) & -0.015 & $-3.99^{* *}$ \\
Log(instalment payments + 1) & 0.001 & $7.36^{* *}$ \\
Log(premium deposit +1$)$ & 0.003 & $7.18^{* *}$ \\
Characteristics of home & & \\
Dummy existing home c) & 0.103 & $35.33^{* *}$ \\
Dummy apartment d) & 0.002 & 0.63 \\
Dummy back repair of the home e) & 0.007 & 1.47 \\
Characteristics of municipality & & \\
Population density per square kilometre & 0.047 & $5.59^{* *}$ \\
Number of inhabitants & 0.001 & 0.88 \\
Log(average value of homes) & 0.007 & 1.22 \\
Benchmark interest rate & & \\
Interest on 10-year government bonds (at date of purchase of mortgage) & 0.070 & $5.18^{* *}$ \\
Intercept & 6.812 & $70.93^{* *}$ \\
$\sigma_{a}$ & 0.152 & \\
$\sigma_{v}$ & 0.294 & \\
$F$-test on age class (six dummies) & $3.40^{* *}$ & \\
$F$-test on calendar month (68 dummies) & $1090^{* *}$ & \\
$F$-test on lender effects (71 dummies) & $140^{* *}$ & \\
Number of observations & & 84,727 \\
\hline & & \\
\hline
\end{tabular}
a) Reference group: age over 50 years.
b) Reference group: one borrower.
c) Reference group: new homes.
d) Reference group: remaining homes, other than apartments.
e) Reference group: no back repair of home.
${ }^{* *}$ Statistically different from zero at $1 \%$ level.

\subsection{Transparency of the Market}

We estimated equation (4) using the explanatory variables discussed in the previous sub-section. Table 5 presents the fixed-effect estimates (72 lenders), 
for which, additionally, 68 dummies of the calendar month were included ${ }^{19}$. The dispersion of the estimated parameters of the lender-specific dummy variables is quite substantial. The standard deviation of the estimated coefficients on these dummy variables, $\sigma_{a}$, is 0.152 . Hence, the dispersion of the lending rate across lenders that we observed in section 4 is still prevalent after correcting for the other explanatory variables. Reformulated, a 95\% interval estimate of the lender-specific coefficients (across the lenders) is 0.61 percentage point ${ }^{20}$. This variation is 0.35 percentage point smaller than the $95 \%$ interval estimate of the average lending rate (across the lenders), which is 0.96 percentage point (see section 4). These results are close to the results found by Heffernan (2002), who finds for the UK a price dispersion of 0.45 percentage point for new borrowers. In her sample, both banks and non-banks, such as building societies and 'community' building societies, are included. Furthermore, she uses interest rates quoted before the actual decision on type of mortgage is made. In that respect, this study is also very comparable to our approach of using one type of mortgage.

Another estimation result is that $\sigma_{a}(0.152)$ is smaller than the standard deviation of the error term $\left(\sigma_{v}=0.294\right)$, which is not in line with our findings of section 4 . It implies that dispersion of the lending rate across lenders is larger than the dispersion within lenders.

Ideally, in our regressions we would like to take into account all borrower's characteristics as observed by the lender. It could be that lenders have information available on the quality of the borrowers (e.g. profession, which is not included in the data set we used). Although these unobserved characteristics affect price dispersion between borrowers, these characteristics will only affect the price dispersion between lenders when individual lenders would target specific groups of borrowers. For this we have no indications.

Next, we discuss the estimated coefficients on the remaining explanatory variables. The logarithm of the loan-to-value ratio has a statistically significant coefficient. The value of -0.117 indicates that a $10 \%$ increase of the loan-to-value ratio leads to a decrease of the lending rate by 0.012 percentage point, so that borrowers who are more restricted have a lower lending rate. Apparently, borrowers with a higher loan-to-value ratio have a lower prepayment risk (as mentioned before, the NMG-insurance leads to an absence of the risk of default).

The loan-to-income ratio is statistically insignificant. We can identify the separate effect of income: A 10\% increase in the income of the head of the household leads to a decrease in lending rate by 0.0033 percentage point. For the income of the partner, this effect is even about ten times smaller. In

19 We do not include additional lender-specific explanatory variables, as these effects will be picked up by the lender dummies.

20 Four times the standard deviation of the fixed effect. The standard deviation is measured in terms of percentage points. 
addition, an increase of the mortgage loan by $10 \%$ leads to a decrease in the lending rate by 0.012 percentage point; whereas an increase of the value of the home by $10 \%$ leads to an increase in the lending rate by 0.012 percentage point.

With respect to the borrower's characteristics, the $F$-test indicates that the age dummies are jointly significantly different from zero. However, the coefficients on the dummies are individually insignificant and no clear pattern emerges from the estimated coefficients. It indicates that there is no indication for third-degree price discrimination between age groups.

The home variables may provide some indication about the impact of collateral. The lending rate is 0.103 percentage point higher for existing homes. For apartments and back repair of the home we find no significant estimated coefficients. These findings imply that the value of the collateral reduces the lending rate. Newly built homes have a higher value. These findings are in line with the results of Wette (1983). Nothaft and Perry (2002) show that neighbourhoods with new homes have lower lending rates. The estimates imply that borrowers in highly populated areas have higher lending rates, but from an economic point of view this effect is very small.

The estimated coefficient on the interest on bonds is 0.07: A 1-percentage point increase in the interest rate on bonds leads to an increase in the lending rate by 0.07 percentage point, ceteris paribus on all explanatory variables (included the monthly calendar dummies) ${ }^{21}$. This coefficient is very small when we compare it with previous estimates for the Dutch mortgage market. Den Butter et al. (1977, pp. 59) estimate the effect of the bond rate on the lending rate of mortgages (homes and other mortgages), for which they use quarterly data over the period 1960:II-1974:I. The estimated parameter on the bond rate is 0.718 . Swank (1995) obtains a value of 0.67 for the effect of the government long-term bond yield on the mortgage lending rate, for which he uses annual data over the period 1957-1990. The difference between our estimate of 0.07 with those of the two aformentioned studies could be explained by the fact that we measure the 10-year bond rate at a daily level, whereas Den Butter et al. (1977) and Swank (1995) measure the bond yield at a quarterly and annual level, respectively. Our estimation results suggest that the effect of the bond rate becomes substantially smaller when allowing for variation at the daily level.

\subsection{Middlemen}

We argued in section 2 that banks may have lower agency costs, because of previous financial transactions with the borrowers. In contrast, agency costs are higher for insurers and pension funds, since they get their information

21 When we exclude the 68 calendar month dummies, the estimated coefficient on the government bonds becomes 0.79 . 


\section{TABLE 6 - ESTIMATES OF EQUATION (4); DEPENDENT VARIABLE: LENDING RATE; DISTINGUISHED BY BANKS AND INSURERS AND PENSION FUNDS; ROBUST STANDARD ERRORS}

\begin{tabular}{|c|c|c|c|c|}
\hline \multirow[t]{2}{*}{ Explanatory variable } & \multicolumn{2}{|c|}{ Banks } & \multicolumn{2}{|c|}{$\begin{array}{l}\text { Insurance companies, } \\
\text { pension funds }\end{array}$} \\
\hline & Parameter & $t$-value & Parameter & $t$-value \\
\hline \multicolumn{5}{|l|}{ Characteristics of borrower } \\
\hline Log(income of head household) & -0.038 & $-8.17^{* *}$ & -0.021 & $-3.05^{* *}$ \\
\hline Log(income of partner +1$)$ & -0.004 & $-8.53^{* *}$ & -0.002 & $-2.52^{* *}$ \\
\hline $\log [$ Loan/(value of home $)]$ & -0.124 & $-17.17^{* *}$ & -0.102 & $-9.71^{* *}$ \\
\hline \multicolumn{5}{|l|}{$\log [$ Loan/(gross income head + } \\
\hline Dummy age $\leq 25$ years ${ }^{\text {a) }}$ & -0.009 & -0.64 & 0.033 & 1.61 \\
\hline Dummy $25<$ age $\leq 30$ years & -0.023 & -1.68 & 0.025 & 1.25 \\
\hline Dummy $30<$ age $\leq 35$ years & -0.019 & -1.40 & 0.025 & 1.26 \\
\hline Dummy $35<$ age $\leq 40$ years & -0.021 & -1.54 & 0.037 & 1.81 \\
\hline Dummy $40<$ age $\leq 45$ years & -0.009 & -0.63 & 0.025 & 1.16 \\
\hline Dummy $45<$ age $\leq 50$ years & -0.019 & -1.25 & 0.015 & 0.64 \\
\hline Dummy more than one borrower ${ }^{b}$ ) & -0.012 & $-2.77^{* *}$ & -0.019 & $-3.12^{* *}$ \\
\hline Log(instalment payments +1$)$ & 0.001 & $5.89^{* *}$ & 0.001 & $2.82^{* *}$ \\
\hline $\log ($ premium deposit +1$)$ & 0.003 & $6.32^{* *}$ & 0.003 & $3.20^{* *}$ \\
\hline \multicolumn{5}{|l|}{ Characteristics of home } \\
\hline Dummy existing home ${ }^{c)}$ & 0.105 & $29.79^{* *}$ & 0.091 & $18.10^{* *}$ \\
\hline Dummy apartment ${ }^{\text {d) }}$ & 0.001 & 0.21 & -0.004 & -0.72 \\
\hline Dummy back repair of the home ${ }^{\mathrm{e})}$ & 0.004 & 0.68 & 0.014 & 1.42 \\
\hline \multicolumn{5}{|l|}{ Characteristics of municipality } \\
\hline Population density per square kilometre & 0.053 & $5.07^{* *}$ & 0.039 & $2.83^{* *}$ \\
\hline Number of inhabitants & 0.002 & 1.56 & -0.001 & -0.62 \\
\hline $\log$ (average value of homes) & 0.010 & 1.47 & 0.002 & 0.17 \\
\hline \multicolumn{5}{|l|}{ Benchmark interest rate } \\
\hline \multicolumn{5}{|l|}{ Interest on 10 -year government } \\
\hline Intercept & 6.773 & $56.46^{* *}$ & 5.189 & $42.33^{* *}$ \\
\hline$\sigma_{a}$ & 0.117 & & 0.162 & \\
\hline$\sigma_{v}$ & 0.303 & & 0.267 & \\
\hline$F$-test on age class (six dummies) & $3.65^{* *}$ & & 1.55 & \\
\hline$F$-test on calendar month (68 dummies) & $843^{* *}$ & & $98^{* *}$ & \\
\hline \multicolumn{5}{|l|}{$F$-test on lender effects ( 20 dummies: } \\
\hline$R$-squared & 0.785 & & 0.805 & \\
\hline Number of observations & 59 , & & & 293 \\
\hline
\end{tabular}

a) Reference group: age over 50 years. b) Reference group: one borrower. c) Reference group: new homes. d) Reference group: remaining homes other than apartments. e) Reference group: no back repair of home. ${ }^{* *}$ Statistically different from zero at $1 \%$ level. 
through middlemen only. We estimated equation (4) for the category banks (21 lenders) and the category insurers and pension funds (51 lenders) separately (see Table 6). We find that $\sigma_{a}$ is smaller for banks $(0.117)$ than for insurers and pension funds (0.162). This difference indicates that lenders that make use of middlemen only may have higher agency costs. In contrast, we find that $\sigma_{v}$ is larger for banks than for insurers and pension funds $(0.303$ versus 0.267 ). A likely explanation for the larger residual variation for banks is that they have applied additional characteristics of the borrower that are not captured by the administrative information that we use in the regression equation. Probably, part of this additional information may be collected through previous contacts with the borrower.

With respect to the effects of the other explanatory variables, the differences between banks and the other lenders are not very substantial, except for the effect of the interest on 10-year government bonds. Our estimates imply that for banks, an increase in the bond rate by 1 percentage point leads to an increase in the lending rate of 0.082 percentage point. Since banks attract funds mainly from the bond market, the bond rate represents the marginal costs of attracting funding to finance mortgages for banks. For the insurers and pension funds the estimated coefficient is not statistically different from zero. The coefficient on the bond rate has a different interpretation for insurance companies, as they mainly invest in the bond market in contrast to banks that mainly attract funds from the bond market. Here the bond rate reflects their opportunity costs of alternative investments in bonds (Boshuizen and Pijpers, 2000).

Next, we consider the differences between the lenders for a period of decrease in the lending rate (44 months) and a period of increase in the lending rate at the market level ( 25 months). According to the estimates, $\sigma_{a}$ is smaller for banks than for the other lenders when there is a decrease in the lending rate $(0.112$ versus 0.168 percentage point, which can be recalculated as a $95 \%$ interval estimate: 0.45 and 0.67 percentage point, respectively). See the first columns of Tables 7 and 8. It may indicate that agency costs are lower for banks than for other lenders that make use of middlemen only.

The estimated error term $\sigma_{v}$ is somewhat larger for banks than for the other lenders ( 0.265 versus 0.296 percentage point), which may reflect that in their assessment of the creditworthiness of borrowers, banks made use of additional information that is not captured by the administrative information.

\section{CONCLUSION}

The empirical results in this paper have opened an avenue towards a new type of empirical microeconomic research of the Dutch mortgage market. This type of research registers and explains dispersion of lending rates across lenders. For a narrowly defined set of endowment mortgages (fixed rate for 
TABLE 7 - ESTIMATES OF EQUATION (4); DEPENDENT VARIABLE: LENDING RATE; BANKS DISTINGUISHED BY CHANGE IN MARKET LENDING RATE; ROBUST STANDARD ERRORS

\begin{tabular}{|c|c|c|c|c|}
\hline \multirow[t]{2}{*}{ Explanatory variable } & \multicolumn{2}{|c|}{$\begin{array}{l}\text { Decrease in market } \\
\text { lending rate }\end{array}$} & \multicolumn{2}{|c|}{$\begin{array}{l}\text { Increase in market } \\
\text { lending rate }\end{array}$} \\
\hline & Parameter & $t$-value & Parameter & $t$-value \\
\hline \multicolumn{5}{|l|}{ Characteristics of borrower } \\
\hline Log(income of head household) & -0.033 & $-5.72^{* *}$ & -0.045 & $-5.88^{* *}$ \\
\hline $\log ($ income of partner +1$)$ & -0.004 & $-6.55^{* *}$ & -0.004 & $-5.30^{* *}$ \\
\hline $\log [\operatorname{Loan} /($ value of home) $]$ & -0.117 & $-12.92^{* *}$ & -0.134 & $-11.36^{* *}$ \\
\hline \multicolumn{5}{|l|}{$\log [$ Loan/(gross income head + gross } \\
\hline Dummy age $\leq 25$ years $^{\text {a) }}$ & 0.002 & 0.12 & -0.028 & -1.43 \\
\hline Dummy $25<$ age $\leq 30$ years & -0.015 & -0.81 & -0.037 & -1.93 \\
\hline Dummy $30<$ age $\leq 35$ years & -0.009 & -0.51 & -0.037 & -1.89 \\
\hline Dummy $35<$ age $\leq 40$ years & -0.014 & -0.73 & -0.034 & -1.72 \\
\hline Dummy $40<$ age $\leq 45$ years & -0.002 & -0.08 & -0.023 & -1.11 \\
\hline Dummy $45<$ age $\leq 50$ years & -0.002 & -0.09 & -0.047 & $-2.13^{*}$ \\
\hline Dummy more than one borrower ${ }^{\text {b) }}$ & -0.016 & $-2.80^{* *}$ & -0.007 & -0.89 \\
\hline Log(instalment payments +1$)$ & 0.001 & $4.69^{* *}$ & 0.001 & $3.39^{* *}$ \\
\hline $\log ($ premium deposit +1$)$ & 0.004 & $6.31^{* *}$ & 0.002 & $2.29^{*}$ \\
\hline \multicolumn{5}{|l|}{ Characteristics of home } \\
\hline Dummy existing home ${ }^{\mathrm{c}}$ & 0.104 & $23.85^{\text {** }}$ & 0.105 & $17.68^{* *}$ \\
\hline Dummy apartment ${ }^{\mathrm{d})}$ & 0.004 & 0.78 & -0.004 & -0.61 \\
\hline Dummy back repair of the home $e^{\mathrm{e})}$ & 0.002 & 0.22 & 0.008 & 0.85 \\
\hline \multicolumn{5}{|l|}{ Characteristics of municipality } \\
\hline Population density per square kilometre & 0.047 & $3.76^{* *}$ & 0.060 & $3.32^{* *}$ \\
\hline Number of inhabitants & 0.001 & 0.92 & 0.003 & 1.33 \\
\hline $\log$ (average value of homes) & 0.013 & 1.54 & 0.004 & 0.38 \\
\hline \multicolumn{5}{|l|}{ Benchmark interest rate } \\
\hline \multicolumn{5}{|l|}{ Interest on 10-year government bonds (at } \\
\hline Intercept & 5.163 & $48.24^{* *}$ & 6.818 & $33.54^{* *}$ \\
\hline$\sigma_{a}$ & 0.112 & & 0.160 & \\
\hline$\sigma_{v}$ & 0.296 & & 0.312 & \\
\hline$F$-test on age class (six dummies) & $3.28^{* *}$ & & 1.44 & \\
\hline \multicolumn{5}{|l|}{$F$-test on calendar month ( 43 dummies: } \\
\hline decrease; 24 dummies: increase) & $372^{* *}$ & & $965^{* *}$ & \\
\hline$F$-test on lender effects ( 20 dummies) & $172^{* *}$ & & $75^{* *}$ & \\
\hline$R$-squared & 0.745 & & 0.816 & \\
\hline Number of observations & & & & \\
\hline
\end{tabular}

a) Reference group: age over 50 years. b) Reference group: one borrower. c) Reference group: new homes. d) Reference group: remaining homes other than apartments. e) Reference group: no back repair of home. ${ }^{*}$ Statistically different from zero at $5 \%$ level. ${ }^{* *}$ Statistically different from zero at $1 \%$ level. 
TABLE 8 - ESTIMATES OF EQUATION (4); DEPENDENT VARIABLE: LENDING RATE; INSURERS AND PENSION FUNDS DISTINGUISHED BY CHANGE IN MARKET LENDING RATE; ROBUST STANDARD ERRORS

\begin{tabular}{|c|c|c|c|c|}
\hline \multirow[t]{2}{*}{ Explanatory variable } & \multicolumn{2}{|c|}{$\begin{array}{l}\text { Decrease in mar- } \\
\text { ket lending rate }\end{array}$} & \multicolumn{2}{|c|}{$\begin{array}{l}\text { Increase in market } \\
\text { lending rate }\end{array}$} \\
\hline & Parameter & $t$-value & Parameter & $t$-value \\
\hline \multicolumn{5}{|l|}{ Characteristics of borrower } \\
\hline Log(income of head household) & -0.019 & $-2.32^{*}$ & -0.024 & $-2.14^{*}$ \\
\hline $\log ($ income of partner +1$)$ & -0.001 & -1.89 & -0.002 & -1.87 \\
\hline $\log [\operatorname{Loan} /($ value of home) $]$ & -0.097 & $-7.42^{* *}$ & -0.111 & $-6.34^{* *}$ \\
\hline \multicolumn{5}{|l|}{$\log [$ Loan/(gross income head + gross } \\
\hline Dummy age $\leq 25$ years $^{\mathrm{a})}$ & 0.023 & 0.96 & 0.047 & 1.33 \\
\hline Dummy $25<$ age $\leq 30$ years & 0.023 & 0.95 & 0.027 & 0.76 \\
\hline Dummy $30<$ age $\leq 35$ years & 0.023 & 0.98 & 0.027 & 0.75 \\
\hline Dummy $35<$ age $\leq 40$ years & 0.039 & 1.59 & 0.033 & 0.91 \\
\hline Dummy $40<$ age $\leq 45$ years & 0.018 & 0.71 & 0.036 & 0.97 \\
\hline Dummy $45<$ age $\leq 50$ years & 0.005 & 0.19 & 0.026 & 0.66 \\
\hline Dummy more than one borrower ${ }^{\text {b) }}$ & -0.024 & $-3.15^{* *}$ & -0.009 & -0.89 \\
\hline Log(instalment payments +1$)$ & 0.001 & $2.58^{* *}$ & 0.001 & 1.49 \\
\hline $\log ($ premium deposit +1$)$ & 0.003 & $3.14^{* *}$ & 0.002 & 1.22 \\
\hline \multicolumn{5}{|l|}{ Characteristics of home } \\
\hline Dummy existing home ${ }^{\mathrm{c}}$ & 0.092 & $14.49^{* *}$ & 0.087 & $10.52^{* *}$ \\
\hline Dummy apartment ${ }^{\mathrm{d})}$ & 0.000 & -0.03 & -0.012 & -1.32 \\
\hline Dummy back repair of the home ${ }^{\mathrm{e}}$ & 0.011 & 0.87 & 0.018 & 1.13 \\
\hline \multicolumn{5}{|l|}{ Characteristics of municipality } \\
\hline Population density per square kilometre & 0.047 & $2.81^{* *}$ & 0.027 & 1.09 \\
\hline Number of inhabitants & -0.002 & -1.20 & 0.002 & 0.63 \\
\hline $\log ($ average value of homes) & 0.000 & -0.01 & 0.005 & 0.33 \\
\hline \multicolumn{5}{|l|}{ Benchmark interest rate } \\
\hline \multicolumn{5}{|l|}{ Interest on 10 -year government bonds } \\
\hline Intercept & 6.910 & $34.39^{* *}$ & 4.986 & $24.50^{* *}$ \\
\hline$\sigma_{a}$ & 0.168 & & 0.161 & \\
\hline$\sigma_{v}$ & 0.265 & & 0.268 & \\
\hline$F$-test on age class (six dummies) & 1.34 & & 1.35 & \\
\hline \multicolumn{5}{|l|}{$F$-test on calendar month ( 43 dummies: } \\
\hline$F$-test on lender effects ( 50 dummies) & $276^{* *}$ & & $25^{* *}$ & \\
\hline$R$-squared & 0.767 & & 0.853 & \\
\hline Number of observations & 16 , & & & \\
\hline
\end{tabular}

a) Reference group: age over 50 years. b) Reference group: one borrower. c) Reference group: new homes. d) Reference group: remaining homes other than apartments. e) Reference group: no back repair of home. ${ }^{*}$ Statistically different from zero at $5 \%$ level. ${ }^{* *}$ Statistically different from zero at $1 \%$ level. 
10 years), we find that a $95 \%$ interval estimate of the monthly average lending rate across lenders is about 0.96 percentage point. However, dispersion within lenders (across borrowers) is larger than the variation between lenders. In addition, the interval estimate reduces to 0.61 percentage point, after correcting for the underlying borrowers' characteristics, the municipality and the government bond rate.

Price dispersion may hint at the presence of imperfect competition, caused by search costs of borrowers or by agency costs of lenders. In general, this points to a lack of transparency, which impedes competition on the mortgage market. We observe substantial differences in price dispersion between the mortgages of banks on the one hand and the mortgages of insurers and pension funds on the other. After correcting for the household and municipality characteristics, we find that the dispersion of the lending rate across lenders is smaller for the banks ( $95 \%$ interval estimate: 0.45 percentage point) than for the other lenders that make use of middlemen only $(95 \%$ interval estimate: 0.67 percentage point). This difference may be caused by a difference in agency costs between banks and insurers due to unobserved characteristics of the lenders. Banks are able to screen borrowers more thoroughly, as they have relatively more direct contact with their borrowers, whereas insurers and pension funds make use of middlemen, who may screen the borrowers less effectively.

\section{REFERENCES}

Boshuizen, G.R. and J.R. Pijpers (2000), 'Toezicht op het beleggingsbeleid van pensioenfondsen en verzekeraars: de rol van de Pensioen-\& Verzekeringskamer' ('Supervision on the Investment Strategy of Pension Funds and Insurance Companies: The Role of the Pensions and Insurance Supervisory Authority of The Netherlands'), PVK-studies 8.

Cameron, A.C. and P.K. Trividi (2005), Microeconometrics, Methods and Applications, Cambridge, Cambridge University Press.

Chiang, R.C. and Y.-F. Chow (2002), 'Residential Mortgage Lending and Borrower Risk: The Relationship Between Mortgage Spreads and Individual Characteristics,' Journal of Real Estate Finance and Economics, 25(1), pp. 5-32.

Den Butter, F.A.G., A.M. Dongelmans and M.M.G. Fase (1977), 'De vraag naar hypothecair krediet en de rentevorming op de hypotheekmarkt' ('The Demand for Mortgage Credit and the Mortgage Rate in The Netherlands'), De Economist, 125 (1), pp. 43 - 74. Reprinted in: Fase, M.M.G. (ed.), (1999), On Interest Rates and Assets Prices in Europe: The Selected Essays of Martin M. G. Fase, Edward Elgar, pp. 147-169.

Diamond, P. (1971), 'A Model of Price Adjustment,' Journal of Economic Theory, 3(3), pp. $156-168$. 
Duca, J.V. and S.S. Rosenthal (1994), 'Do Mortgage Rates Vary Based on Household Default Characteristics? Evidence on Rate Sorting and Credit Rationing,' Journal of Real Estate Finance and Economics, 8(2), pp. 99-113.

Fase, M.M.G. (1995), 'The Demand for Commercial Bank Loans and the Lending Rate,' European Economic Review, 39(1), pp. 99-115.

de Haas, R.T.A., A.C.F.J. Houben, J.I. Kakes and H. Korthorst (2000), 'De kredietverlening door Nederlandse banken' ('Loan supply by Dutch Banks'), DNB monetaire monografieën, no. 18.

Heffernan, S.A. (2002), 'How do UK Financial Institutions Really Price Their Banking Products?', Journal of Banking and Finance, 26(10), pp. 1997-2016.

Lach, S. (2002), 'Existence and Persistence of Price Dispersion: An Empirical Analysis,' Review of Economics and Statistics, 84(3), pp. 433-444.

Merriken, H.E. (1988), 'Mortgage Loan Market Segmentation and Lender Pricing Behavior,' Journal of Real Estate Research, 3(1), pp. 9-18.

NERA (1999), Assessing Mergers in the Insurance Sector in The Netherlands: A Report for the Nederlandse Mededingingsautoriteit, London.

NHG (2002), 'Verkenningen NHG 1995-2001' ('Explorations by the National Mortage Guarantee (NMG) 1995-2001'), Zoetermeer, The Netherlands.

Nothaft, F.E. and V.G. Perry (2002), 'Do Mortgage Rates Vary by Neighborhood? Implications for Loan Pricing and Redlining,' Journal of Housing Economics, 11(3), pp. 244-265.

Salop, S. and J. Stiglitz (1977), 'Bargain and Rip-offs: A model of Monopolistically Competitive Price Dispersion,' Review of Economic Studies, 44(3), pp. 493-510.

Swank, J. (1995), 'Oligopoly in Loan and Deposit Markets: An Econometric Application to The Netherlands,' De Economist, 143(3), pp. 355-366.

Toolsema, L.A. (2002), 'Competition in the Dutch Consumer Credit Market,' Journal of Banking and Finance, 26(11), pp. 2215-2219.

Toolsema, L.A. and J. Jacobs (2001), Why do Prices Rise Faster than They Fall? With an Application to Mortgage Rates, Groningen, mimeo University of Groningen.

Wette, H.C. (1983), 'Collateral in Credit Rationing in Markets with Imperfect Information: Note,' American Economic Review, 73(3), pp. 442-445. 